\title{
SOSIALISASI ANEMIA PADA IBU HAMIL DI DESA SUNGAI SARIK TAHUN 2017
}

\author{
Ani Triana \\ STIKes Hang Tuah Pekanbaru
}

\begin{abstract}
Anemia occurs due to low hemoglobin content in the body during pregnancy. This pregnancy anemia can be simply defined by the lack of red blood cells in the blood than usually less than $11 \mathrm{~g} \%$. Sungai Sarik village with a very isolated location and minimal health facilities is very difficult to obtain information and treatment of anemia. They are forced to go to a dukun when they experience complaints. There are 10 pregnant women in the area, out of 10 pregnant women they do not know about anemia in pregnant women. To increase knowledge and information about anemia in pregnant women in Sungai Sarik Village. The method of activity carried out is to provide counseling and examination of anemia in pregnant women. Before counseling about anemia socialization to pregnant women, questions were asked to pregnant women about anemia, 7 out of 10 pregnant women did not know about anemia. Then after counseling and examinations, it was found that the mother's knowledge had increased, from 10 pregnant women 8 people understood anemia and its treatment. Then from the examination obtained from 10 pregnant women, there were 7 people who had mild anemia. The need for synergy coordination between Puskesmas and Health Workers in the Sarik River area.
\end{abstract}

Keyword $\quad$ : Anemiia in Pregnant Women, Sungai Sarik

\begin{abstract}
ABSTRAK
Anemia terjadi akibat rendahnya kandungan hemoglobin dalam tubuh semasa mengandung. Anemia kehamilan ini secara sederhana dapat kita artikan dengan kurangnya sel-sel darah merah di dalam darah daripada biasanya kurang dari $11 \mathrm{gr} \%$. Desa Sungai Sarik dengan lokasi yang sangat terisolir dan minim fasilitas kesehatan sangat sulit mendapatkan informasi dan penanganan anemia. Mereka terpaksa ke dukun apabila mengalami keluhan. Terdapat $10 \mathrm{ibu}$ hamil berada di wilayah tersebut, dari $10 \mathrm{ibu}$ hamil mereka tidak mengetahui tentang anemia pada ibu hamil. Untuk meningkatkan pengetahuan dan informasi tentang anemia pada ibu hamil di Desa Sungai Sarik. Metode kegiatan yang dilakukan adalah dengan melakukan penyuluhan dan pemeriksaan anemia pada ibu hamil. Sebelum dilakukan penyuluhan tentang Sosialisasi Anemia pada Ibu Hamil, dilakukan pertanyaan kepada ibu hamil tentang anemia, dari 7 dari 10 ibu hamil tidak mengetahui tenatang anemia. Lalu setelah dilakukan penyuluhan dan pemeriksaan didapatkan pengetahuan ibu meningkat, dari 10 orang ibu hamil 8 orang mengerti tentang anemia dan penanganannya. Lalu dari pemeriksaan didapatkan dari 10 orang ibu hamil terdapat 7 orang yang mengalami anemia ringan. Perlunya koordinasi yang sinergi antara Puskesmas dan Tenaga Kesehatan yang berada di wilayah Sungai Sarik.
\end{abstract}

Kata Kunci

: Anemia pada Ibu Hamil, Sungai Sarik

\section{PENDAHULUAN}

Masa kehamilan merupakan masa dimana tubuh sangat membutuhkan asupan makan yang maksimal baik untuk jasmani maupun rohani (selalu rileks dan tidak stress). Di masa-masa ini pula, wanita hamil sangat rentan terhadap menurunnya kemampuan tubuh untuk bekerja secara maksimal. Wanita hamil biasanya sering mengeluh sering letih, kepala pusing, sesak nafas, wajah pucat dan berbagai macam keluhan lainnya. 
Semua keluhan tersebut merupakan indikasi bahwa wanita hamil tersebut sedang menderita anemia pada masa kehamilan.

Penyakit ini terjadi akibat rendahnya kandungan hemoglobin dalam tubuh semasa mengandung. Anemia kehamilan ini secara sederhana dapat kita artikan dengan kurangnya sel-sel darah merah di dalam darah daripada biasanya kurang dari $11 \mathrm{gr} \%$.

Anemia pada kehamilan di Indonesia masih tinggi, dengan angka nasional $65 \%$ yang setiap daerah mempunyai variasi berbeda. Anemia gangguan medis yang paling umum ditemui pada masa hamil, mempengaruhi sekurang - kurangnya $20 \%$ wanita hamil. Wanita ini memiliki insiden komplikasi puerperal yang lebih tinggi, seperti infeksi, daripada wanita hamil dengan nilai hematologi normal.

Anemia menyebabkan penurunan kapasitas darah untuk membawa oksigen. Jantung berupaya mengonpensasi kondisi ini dengan meningkatkan curah jantung. Upaya ini meningkatkan kebebasan kerja jantung dan menekan fungsi ventricular. Dengan demikian, anemia yang menyertai komplikasi lain (misalnya, preeklampsia) dapat mengakibatkan jantung kongestif.

\section{PERUMUSAN MASALAH}

Desa Sungai Sarik dengan lokasi yang sangat terisolir dan minim fasilitas kesehatan sangat sulit mendapatkan informasi dan penanganan anemia. Mereka terpaksa ke dukun apabila mengalami keluhan. Terdapat $10 \mathrm{ibu}$ hamil berada di wilayah tersebut, dari 10 ibu hamil mereka tidak mengetahui tentang anemia pada ibu hamil. Oleh karena itu penulis tertarik melakukan pengabdian kepada masyarakat dengan judul "Sosialisasi Anemia Pada Ibu Hamil di Desa Sungai Sarik Tahun 2017"

\section{TUJUAN KEGIATAN}

Untuk meningkatkan pengetahuan dan informasi tentang anemia pada ibu hamil di Desa Sungai Sarik.

\section{METODE}

Metode kegiatan yang dilakukan adalah dengan melakukan penyuluhan dan pemeriksaan anemia pada ibu hamil.

\section{HASIL}

Sebelum dilakukan penyuluhan tentang Sosialisasi Anemia pada Ibu Hamil, dilakukan pertanyaan kepada ibu hamil tentang anemia, dari 7 dari $10 \mathrm{ibu}$ hamil tidak mengetahui tenatang anemia dan semua ibu hamil tidak tahu bagaimana penanganan anemia atau adanya pemberian teblet Fe sebanyak 90 
tablet selama masa kehamilan. Lalu setelah dilakukan penyuluhan dan pemeriksaan didapatkan pengetahuan ibu meningkat, dari 10 orang ibu hamil 8 orang mengerti tentang anemia dan penanganannya. Lalu dari pemeriksaan didapatkan dari 10 orang ibu hamil terdapat 7 orang yang mengalami anemia ringan.

\section{PEMBAHASAN}

Pelaksanaan kegiatan dilakukan di Balai Desa Sungai Sarik Kabupaten Kampar. Dihadiri sebanyak 10 orang Ibu hamil, didapatkan dari 10 orang ibu hamil, 7 diantaranya mengalami anemia ringan pada kehamilan.

Susunan acara sebagai berikut: Pembukaan5 menit oleh moderator Ade Irma Suryani, SEI. Kegiatan Penyuluhan pada pendahuluan pertama yaitu menyampaikan salam, kedua menjelaskan tujuan kemudian kontrak waktu. Kegiatan Ibu Membalas, Mendengarkan dan Memberi respon. kemudian acara inti 15 menit materipenyuluhan disampaikan oleh Ani Triana, SST, M.Kes sebagai pemateri, isi materi Pengertian anemiapada ibu hamil,Ciri-ciri anemia padaibu hamil, Macam -macamanemia, Akibat anemia padaibu hamil, Penatalaksanaan dan pengobatan anemia dan Cara meminum tabletzat besi yang benar. Kegiatan ibu
Menanyakan yang belum jelas. Aktif bersama menyimpulkan, membalas salam dan terakhir penutup 10 menit . Kegiatan selanjutnya yaitu tanya jawab, tes akhir, menyimpulkan hasil penyuluhan dan memberi salam. Penutup. Kegiatan ibu menanyakan yang belum jelas, aktif bersama menyimpulkan dan memberikan dorprize pada ibu yang dapat menjawab pertanyaan yang diberikan moderator.

\section{KESIMPULAN}

Berdasarkan kegiatan pengabdian kepada masyarakat tersebut yang dihadiri 10 orang Ibu hamil, didapatkan dari 10 orang ibu hamil, 7 diantaranya mengalami anemia ringan pada kehamilan.

\section{SARAN}

Diharapkan kepada tenaga kesehatan untuk selalu berada di Desa untuk melakukan kegiatan rutin seperti pemeriksaan ibu hamil, konseling, dan pelayanan lain yang berkaitan dengan Kesehatan Ibu dan Anak. Perlunya koordinasi yang sinergi antara Puskesmas dan Tenaga Kesehatan yang berada di wilayah Sungai Sarik.

\section{DAFTAR PUSTAKA}


Morgan Geri, dkk. 2009. Obstetri dan

Ginekologi Panduan Praktik. Jakarta: EGC.

Loowdermilk,dkk.2005.Buku

Ajar

Keperawatan Maternitas. Jakarta : EGC.

Taber Ben-zion,M,D.1994.Kapita Selekta

Kedaruratan Obstet dan

Ginekologi.Jakarta:EGC.

Prawirohardjo, Sarwono.2006.Acuan

Nasional Pelayanan Kesehatan
Meternal

dan

Neonatal.Jakarta:Yayasan

Bina

Pustaka.

Doenges, Marilynn E,dkk.2000.Rencana

Asuhan Keperawatan.Jakarta:EGC.

Nanda.2009.Diagnosa Keperawatan 2009-2011.Jakarta:EGC.

Manuaba, Ida Bagus Gde.2001.Kapita Selekta Penatalaksanaan Rutin Obstetri Ginekologi dan KB.Jakarta:EGC 